\title{
DESIGN AND MANAGEMENT OF IRRIGATION SYSTEMS
}

\author{
Eduardo A. Holzapfel ${ }^{1}$, Alejandro Pannunzio² ${ }^{2}$ Ignacio Lorite $^{3}$, Aureo S. Silva de Oliveira ${ }^{4}$, \\ and István Farkas ${ }^{5}$
}

\begin{abstract}
Irrigation systems should be a relevant agent to give solutions to the increasing demand of food, and to the development, sustainability and productivity of the agricultural sector. The design, managing, and operation of irrigation systems are crucial factors to achieve an efficient use of the water resources and the success in the production of crops and orchards. The aim of this paper is to analyze knowledge and investigations that enable to identify the principal criteria and processes that allow improving the design and managing of the irrigation systems, based on the basic concept that they facilitate to develop agriculture more efficient and sustainable. The design and managing of irrigation systems must have its base in criteria that are relevant, which implies to take into account agronomic, soil, hydraulic, economic, energetic, and environmental factors. The optimal design and managing of irrigation systems at farm level is a factor of the first importance for a rational use of water, economic development of the agriculture and its environmental sustainability.
\end{abstract}

Key words: irrigation, design, water management, operation systems.

\section{INTRODUCTION}

Water required by crops is supplied by nature in the form of precipitation, but when it becomes scarce or its distribution does not coincide with demand peaks, it is then necessary to supply it artificially, by irrigation. Several irrigation methods are available, and the selection of one depends on factors such as water availability, crop, soil characteristics, land topography, and associated cost.

In the near future, irrigated agriculture will need to produce two-thirds of the increase in food products required by a larger population (English et al., 2002). The growing dependence on irrigated agriculture coincides with an

${ }^{1}$ Universidad de Concepción, Facultad de Ingeniería Agrícola, Departamento de Recursos Hídricos, Av. Vicente Méndez 595, Chillán, Chile (eholzapf@udec.cl).

${ }^{2}$ Universidad de Buenos Aires, Departamento de Agronomía, Av. Chorroarin 280, Ciudad Autónoma de Buenos Aires, Buenos Aires, Argentina (alejandropannunzio@gmail.com).

${ }^{3}$ Consejería de Agricultura y Pesca IFAPA, Centro Alameda del Obispo, Junta de Andalucía, Córdoba, España

(ignacioj.lorite@juntadeandalucia.es).

${ }^{4}$ Universidade Federal do Recôncavo da Bahia (UFRB), Núcleo de Engenharia de Água e Solo (NEAS), 44380-000 Cruz das Almas, Bahia,Brasil (aureo@ufrb.edu.br).

${ }^{5}$ Gödöllő University, Department of Physics and Process Control, 2103 Pater Karoly utca 1 Gödöllő, Hungary

(Farkas.Istvan@gek.szie.hu). accelerated competition for water and increased awareness of unintended negative consequences of poor design and management (Cai et al., 2003).

Optimum management of available water resources at farm level is needed because of increasing demands, limited resources, water table variation in space and time, and soil contamination (Kumar and Singh, 2003). Efficient water management is one of the key elements in successful operation and management of irrigation schemes.

Irrigation water management involves determining when to irrigate, the amount of water to apply at each irrigation event and during each stage of plant, and operating and maintaining the irrigation system. The main management objective is to manage the production system for profit without compromising environment and in agreement with water availability. A major management activity involves irrigation scheduling or determining when and how much water to apply, considering the irrigation method and other field characteristics.

Under limitations in water availability, it is required to develop new irrigation scheduling approaches focused on to ensure optimal use of available water, and not based on full crop water requirements. The determination of these efficient and effective irrigation schedules (including deficit irrigation strategies) requires the accurate determination of water requirements for the main crops, in order to assist the 
farmers in deciding when and how much to irrigate their crops.

New technologies such as remote sensing, modeling, and lysimiter are contributing to obtain a better knowledge of the crop agronomy and irrigation, detecting water stress, determining crop water requirements and obtaining accurate irrigation schedules.

Irrigation technology has made significant advances in recent years. Criteria and procedures have been developed to improve and rationalize practices to apply water, through soil leveling, irrigation system design, discharge regulations, adduction structures, and control equipment. However, in many regions these advances are not yet available at the farm stage.

Irrigation systems are selected, designed and operated to supply the irrigation requirements of each crop on the farm while controlling deep percolation, runoff, evaporation, and operational losses, to establish a sustainable production process. Playán and Mateos (2006) mentioned that modernized irrigation systems at farm level implies selecting the appropriate irrigation system and strategy according to the water availability, the characteristics of climate, soil and crop, the economic and social circumstances, and the constraints of the distribution system.

\section{IRRIGATION SYSTEMS}

\section{Design and management}

Design of irrigation systems is a very important topic in the process to improve irrigation application, efficiency and economical return in the production process (Pannunzio et al., 2004b).

Irrigation system design substantially affects application efficiency and involves numerous variables and restrictions, whose principal objective is to maximize benefits and minimize costs. In a successful irrigation system, a set of resources produces maximum returns. To achieve this, an optimization process supporting the design and operation of water application systems in agriculture is required due to many possible combinations of design variables that satisfy irrigation conditions.

Irrigation systems have specific applications that are based in several factors, among which the most relevant are the crop, soil type, topography, and water availability and quality. The application efficiency of the different surface and pressurized irrigation methods varies and depends on design, management, and operation (Holzapfel and Arumí, 2006).

Undoubtedly, well-designed and correctly used irrigation systems will have the highest efficiency and water distribution levels, which can result in a good production and high product quality (Holzapfel et al.,
$2000 ; 2004)$. For an adequate management and operation of the surface irrigation systems, a series of support elements have been developed, including simulation models and control and derivation structures, such as adduction systems. In the case of pressurized irrigation systems, enormous advances have resulted in greater automation in its operation, greater precision in its application, and the incorporation of chemical elements for nutrition and disease control into the irrigation process (Holzapfel and Arumí, 2006; Ravindra et al., 2008).

In order to increase agriculture sustainability, an important aspect that has been considered by several researchers and studies is to design efficient irrigation systems at farm level (Hillel and Vlek, 2005; Khan et al., 2006; Hsiao et al., 2007; Pannunzio et al., 2008; Pannunzio, 2008). These appear to be a very crucial aspect for the irrigated agriculture and a key factor due to the competition for water resources. In recent years, several irrigation systems have improved significantly the application efficiency at farm level, improving the irrigation water management. For instance, in the main irrigation districts of Mexico, introducing new technologies and more efficient associated with real-time irrigation scheduling, demonstrated water savings in the order of at least $20 \%$, without any appreciable decrease in crop yields (Quiñones et al., 1999).

Some studies have analyzed the differences in irrigation efficiency for several irrigation systems, as Al-Jamal et al. (2001), where sprinkler, trickle and furrow irrigation systems were analyzed in Southern New Mexico, USA, with onion production. Thus, the maximum irrigation water use efficiency (IWUE) was obtained using the sprinkler system. The lower IWUE values were obtained under subsurface drip and furrow irrigation systems compared with sprinkler irrigation was due to excessive irrigation under subsurface drip and higher evaporation rates from fields using furrow irrigation.

\section{Comparison of irrigation systems}

Ibragimov et al. (2007) compared drip and furrow irrigation, obtaining that $18-42 \%$ of the irrigation water was saved with drip systems in comparison with furrow, and the IWUE increased by $35-103 \%$ compared with furrow irrigation. Same comparisons were made by Maisiri et al. (2005) in a semi-arid agro tropical climate of Zimbabwe; in this study, drip irrigation used about $35 \%$ of the water used by the surface irrigation systems, providing higher IWUE. The gross margin level for surface irrigation was lower than for drip irrigation.

Other studies analyzed surface and subsurface drip irrigation systems in Turkey (Yazar et al., 2002). Both methods had similar yield results but surface drip had more advantages due to difficulty in replacement and 
higher cost for subsurface systems. Additionally they recommended the surface drip in early potato under Mediterranean conditions.

Tognetti et al. (2003) determined that drip irrigation influenced positively many of the physiological process and technological parameters in semi-arid conditions, as compared to low-pressure sprinkler irrigation. Hanson and May (2004) obtained yield increases when drip system were used compared to the sprinkler systems with similar amounts of applied water; additionally, drips systems reduced percolation below the root zone. Another study analyzed low-energy precision application (LEPA) and trickle irrigation for cotton in Turkey, concluding that both irrigation systems could be used successfully under the arid climatic conditions of this country (Yazar et al., 2002).

\section{Pressurized irrigation systems}

According to many papers, drip irrigation is widely regarded as the most promising irrigation system, and is specially recommended in combination with saline water. In Karlberg et al. (2007) report, two low-cost drip irrigation systems with different emitter discharge rates were used to irrigate tomatoes (Lycopersicon esculentum), concluding that the combination of drip systems with plastic mulch increased the yield.

In relation with drip systems, some analyses have been made to determine the optimum lateral spacing for drip-irrigated corn (Zea mays) in Turkey (Bozkurt et al., 2006). Lateral spacing of $0.7,1.40$ and $2.10 \mathrm{~m}$ were compared, concluding that the optimum lateral spacing for corn was $1.40 \mathrm{~m}$ (one drip lateral per two crop rows). Ravindra et al. (2008) developed a linear programming model for optimal design of pressurized irrigation system subunit, considering implementation cost and energy. Holzapfel et al. (2007a; 2007b) analysed the optimal selection of emitters and sprinkler taking into account the total cost, operation and implementation. Rodríguez et al. (2007) studied the selection of emitter on the basis of hydraulic characteristics. On the other hand, annual water application cost per unit area has been analyzed at the subunit level designed with pipes of different materials by Ortiz Romero et al. (2006).

Other important aspects are related with the analysis of strategies for water management in pressurized irrigation systems (Ramalan and Hill, 2000). The timing or frequency of water applications will depend on soil texture (e.g., sand $v s$. clay), the irrigation system used (e.g., drip $v s$. sprinkler), the rate at which the plant is using water, and the overall development of the plants root system. Frequent water applications are especially important when using drip systems, which tend to restrict soil wetting and thus produce a smaller root system. When done properly, frequent irrigations are beneficial and often increase growth and yield in many orchards and crops. For example, frequent irrigation by drip in peach (Prunus persica) increased fruit size and yield compared to other irrigation methods by maintaining higher tree water status between irrigations (Bryla et al., 2005). It is also important to apply water to both sides of the plant and to maintain an adequate volume of soil wetted, as was observed in citrus (Citrus sp.) and avocados (Persea americana) (Henríquez, 2005; Holzapfel and Arumí, 2006). Abbott and Gough (1986) found that when water was applied to only one side, growth and production were severely restricted on the other. However, irrigators, particularly those using drip, should be careful to avoid the temptation to over-irrigate. Over-irrigation depletes the root zone of much-needed oxygen, thus reducing both root growth and nutrient uptake, leading to a host of potential root disease problems as well as aquifer contamination. Yadav and Mathur (2008) found with tested model that the water extraction is closely related with soil moisture availability in addition to the root density, which occurs normally from the upper root dense soil profile.

Considering the relevant support that means a good automation of the irrigation systems to reduce management time and simplify design, it is necessary to use the modern methods of surveying and analysis tools (Troy Peters and Evett, 2008). Remote sensing and Geographic Information Systems (GIS) with their capability of data collection and analysis are viewed as efficient and effective tools for pressurized irrigation system design and management (Rodriguez, 2001). The capability of GIS to analyze the information across space and time would help in managing such dynamic systems as pressurized irrigation systems. Hazrat et al. (2003) found that the GIS are an important tool that can be used to optimal allocation of water resources of an irrigation project. Mean water balance components results for different months were stored in GIS databases, analyzed, and displayed as the monthly crop water requirements maps.

Intensive irrigated agriculture under pressurized systems involves water application, fertilizers and other chemicals, applied in varying amounts to the crop and orchards areas. Yet, like any enhanced productive activity, it leads to environmental contamination if it is improperly managed (Wichelns and Oster, 2006). When utilization of chemicals is incomplete or inefficient, or when water is applied in excess, the resultant seepage ends up in drainage systems or in recharging the aquifers beneath the cropped land (Hadas et al., 1999).

\section{Surface irrigation systems}

During the past two decades procedures and criteria of surface irrigation have become available, which have 
established the optimum design and efficient management and operation of the water applied to crops to obtain maximum yield and avoid environmental effect due to leaching and runoff.

The most frequently used surface irrigation systems are: contour irrigation, border irrigation, and furrow irrigation. The latter is more frequently used to irrigate row crops and orchards. This method possesses various factors and elements of design and management which have been extensively analyzed.

Furrow irrigation is the oldest and more commonly used irrigation system. Lately, it has become important because of the high cost of energy in pressurized irrigation methods and the incorporation of automation in its operation (Holzapfel and Arumí, 2006). Eldeiry et al. (2005) found in a study of design of furrow irrigation in clay soil that the furrow length and application discharge are the main factor affecting application efficiency. On the other hand, environmental impacts of furrow irrigation has been studied by different researchers (Lehrsch et al., 2000) and has been found that in irrigation, risks of nitrate leaching depends of water and fertilizer application (Popova et al., 2005). Burguete et al. (2009a; 2009b) developed and calibrated a model and methodology for fertigation in furrow irrigation, which allow adequate fertilizer uniformity and avoid contamination problems. The automation of fertilization as well as water application are very important advances for the development of furrow irrigation and the improvement of surface irrigation systems.

The amounts of water and leachates vary with the type of irrigation system used, irrigation efficiency, crop or orchard, utilization of water and fertilizers, decomposition of the added organic materials, and absorption of the decomposed fractions. The leachates contain the chemicals mostly added in irrigation water, but nitrate is the dominant anion, derived from fertilizers and decomposing organic materials. In addition, pesticides are other chemicals incorporated in irrigation and it has been shown that leaching increased in direct relation with the increment of the amount of percolating water produced by irrigation (Asare et al., 2001). The close association between leaching and amount of deep-percolating water produced by irrigation is expected because leaching occurs through dissolution of solute in soil solution and subsequently moves with soil water. These results can show the importance of using an adequate design of surface and pressurized irrigation systems and management techniques to reduce chemical leaching by decreasing deep percolation.

In many irrigated regions of the western United States, commercial growers that use furrow irrigation systems are facing serious challenges to improve irrigation efficiency and reduce contamination of water supplies (Rice $e t$ al., 2001). However, the most important points are to adequately select the irrigation variables in each system with appropriate design criteria, improving the irrigation scheduling and water management of the field that will also potentially reduce over-irrigation and deep leaching of applied water and chemicals.

\section{General considerations}

Design of irrigation systems is a very important topic in the process to improve water application, efficiency and economical return in the production process. To develop adequate engineering design, the use of well known criteria it is a basic component; this can only be obtained with deep knowledge on irrigation, and the technical parameters associated with crop, soil water characteristics, energy and environment. Pereira (1999) reported that to improve the irrigation systems requires the consideration of the factors influencing the hydraulic processes, the water infiltration and the uniformity of water application to the entire field. The consideration of all these aspects makes irrigation management a complex decision making and field practice process.

Playán and Mateos (2006) reported that in general all irrigation systems can attain approximately the same level of efficiency, when they are well designed and appropriated selected for the specific condition, due that irrigation is site specific. However, differences among irrigation systems appear in many areas as a consequence of design, management and maintenance. There are several reports indicating that trickle irrigation systems increased yields in Washington Navel oranges (Citrus sinensis) in humid regions (Pannunzio et al., 2000; Pannunzio and Genoud, 2000), determining the convenience of wetting a minimum percentage of the shaded area by the crop to maximize yields, finding the mini-sprinkler system as the most efficient.

An adequate selection and distribution of number of emitters in drip irrigation may give substantial different results (Rodríguez et al., 2007). Colombo and Or (2006) found that in a drip irrigated field, local crop yield patterns are determined by spatial patterns in water accessibility to plants that could be quantified and used for optimal irrigation system design; the results demonstrated that around each emitter, the spatial distribution of aboveground dry mass per plant followed a general pattern. Number and location of drippers in a blueberry (Vaccinium corimbosum) crop was tested, finding out that the shallow and spread roots of the crop were well wetted by two laterals per each row of crop compared with a single line of drippers per row of crop, resulting in greater yields (Pannunzio et al., 2004a). Henríquez (2005) found that with a correct number and distribution of emitter on the base of soil and plant characteristic, there are differences of $100 \%$ in yield for citrus orchards. 


\section{WATER MANAGEMENT FOR IRRIGATION SYSTEMS}

\section{Deficit irrigation in fruit trees for management of irrigation systems}

The concept of regulated deficit irrigation (RDI) was initially proposed to control vegetative growth in peach orchards, determining in addition savings in irrigation water without reducing yield. Thus, deficit irrigation has been demonstrated as a useful tool to improve the irrigation management at field scale for arid and semi-arid conditions.

Deficit irrigation has been used extensively for annual crops in the past. Thus, was applied to corn (Payero et al., 2006; Farré and Faci, 2006); cotton (Gossypium hirsutum) (Jalota et al., 2006; Falkenberg et al., 2007); wheat (Triticum aestivum) (Jalota et al., 2006); sorghum (Sorghum bicolor) (Farré and Faci, 2006); onion (Allium сера) (Bekele and Tilahun, 2007) and sugar beet (Beta vulgaris) (Fabeiro et al., 2003).

However deficit irrigation has had significantly more success in tree crops and vines than in field crops (Fereres and Soriano, 2007). Analyses of deficit irrigation in trees have been related with peaches (Girona et al., 2005a); almonds (Prunus dulcis) (Romero et al., 2004; Girona et al., 2005b; Romero et al., 2006; Goldhamer et al., 2006); pistachio (Pistacia vera) (Goldhamer and Beede, 2004); plum (Prunus domestica) (Intrigliolo and Castel, 2006); olives (Olea europaea) (Moriana et al., 2003; Tognetti et al., 2006); citrus (Domingo et al., 1996; GonzálezAltozano and Castel, 1999; Velez et al., 2007) and wine grapes (Vitis vinifera) (Bravdo and Naor, 1996; McCarthy et al., 2002). Analyzing all these studies, the conclusion would be that supplying full ET requirements could not be the optimal irrigation scheduling for management of irrigation systems.

A correct water management at field scale is highly influenced by the irrigation method and the irrigation operating system. Traditionally deficit irrigation strategies were carried out on-demand irrigation systems, where the date and rate of the irrigation was decided by the farmer or technician, and the irrigation scheduling was not limited by the distribution system. Equally, for fruit trees drip and micro-sprinkler systems are the most common irrigation methods, although surface irrigation methods under an appropriate water management could provide similar efficiency and performance results.

Authors as Girona et al. (2005a) analysed the response to single and combined deficit irrigation regimes for peach trees with an automated drip system with four compensating emitters per tree. Thus, it was obtained that deficit irrigation during Stage II of fruit development and/ or during post-harvest significantly reduced vegetative growth of the trees. However, fruit production was not affected by any deficit irrigation strategy until the fourth year when yield decreased slightly with combined deficit irrigation (Girona et al., 2005a).

Similar studies were made in almond, applying RDI during the kernel-filling phase (Girona et al., 2005b). In the study during the first two experimental years, kernel dry matter accumulation did not decrease, however, similar to previous works, cropping and kernel growth were reduced during the third and fourth years of experiment due to a hypothetical depletion of the reservoirs. Water savings obtained with these deficit irrigation strategies may help to promote the adoption of regulated deficit irrigation in areas with water availability reduced. The main difference among this experiment and previous analyses was the irrigation system; in this case micro-sprinklers were used. This fact could affect the wetted soil volume. Some authors (Hutmacher et al., 1994) suggested the possibility to obtain better results using micro-sprinklers, confirmed by Girona et al. (2005b) who indicated that wet soil volume was a very important factor for almond. Thus, specific studies comparing drip and micro-sprinklers systems indicated that also for others crops as grapevines irrigated by micro sprinklers, showed greater root presence as the distance from the trunk increased (Bassoi et al., 2003).

Also in almond with micro-sprinkler irrigation, Goldhamer et al. (2006) analyzed the impacts of three different water stress timing patterns. The most successful stress timing pattern in terms of yield (considering fruit size and load) was the pattern that imposed sustained deficit irrigation by applying water a given percentage of full ETc over the entire season. Also Romero et al. (2004) analysed the influence of several RDI strategies under subsurface and surface drip irrigation. Thus, RDI, with a severe irrigation deprivation during kernel-filling (20\% ETc), and a recovery post-harvest at $75 \%$ ETc or up to $50 \%$ ETc under subsurface drip irrigation, can be adequate in almonds under semiarid conditions, saving a significant amount of irrigation water. The comparison between surface and sub-surface irrigation indicated higher levels of volumetric soil water content for subsuperficial systems (Romero et al., 2004).

Comparisons among surface drip, subsurface drip and micro-jet on almonds indicated that micro-jet irrigated trees tended to increase yield about $10 \%$ in some years although no consistent yield differences were found (Edstrom and Schwankl, 2002). Considering growth under deficit irrigation, micro-jet irrigated trees induced slightly higher growth, similar results that when root development was analysed. However, as negative aspect, micro-jet irrigation increased maintenance and required higher use of herbicide. 
Deficit irrigation effects on yield and vegetative development also have been analyzed for drip irrigated olives. Thus, some authors (Tognetti et al., 2006) determined that water availability might affect fruit weight before flowering or during the early stages of fruit growth rather than later in summer season. Thus, irrigation of olive trees with drip systems from the beginning of pit hardening could be recommended, at least in the experimental conditions of the study. Comparing different treatments, deficit irrigation during the whole summer resulted in improved plant water relations with respect to other watering regimes, while severe RDI differentiated only slightly treatments from rain fed plants (Tognetti et al., 2005). Nevertheless, regulated deficit irrigation of olive trees after pit hardening could be recommended. Citrus also has been studied under deficit irrigation strategies. Thus, deficit irrigation treatments compared with the control drip irrigated by six pressure compensated emitters by tree allowed seasonal water saving between 12 and 18\% (Velez et al., 2007).

\section{Recent methodologies applied to the water manage- ment and stress detection}

Several studies about deficit irrigation have used new technologies as remote sensing techniques. The use of infrared thermometry and thermal imaging is considered an interesting option in order to monitoring stress in trees, as Sepulcre-Cantó et al. (2006) described for stress detection in olive trees from infrared imagery. Also Falkenberg et al. (2007) with an infrared camera distinguished between biotic (root rot) and abiotic (drought) stress with the assistance of ground truthing, determining that deficit irrigation around $75 \%$ ETc had no impact on yield, indicating that water savings were possible without reducing yield.

In addition to remote sensing technology, lysimeter also has been used to characterize deficit irrigation and stress for orchard trees as peaches (Girona et al., 2004). In this work it was established threshold levels of available soil water content for ET, leaf conductance and photosynthesis during deficit irrigation periods, demonstrating the importance of considering wetting patterns, soil depth and root exploration in high frequency irrigation management, especially for tree crops.

\section{CONCLUSIONS}

Irrigation system design substantially affects application efficiency and involves numerous variables and restrictions whose principal objectives are to maximize benefits and minimize costs. Design of irrigation systems is a very important topic to improve irrigation application, efficiency and economical return in the production process. The design must be on the basis of sound criteria that are mainly related with knowledge on irrigation, hydraulic, economic, energy, environmental and agronomics aspects.

Efficient irrigation systems design at farm level appear to be a very important aspect for the irrigated agriculture and a key factor due to the competition for water resources with other sectors and to permit the economical and environmental sustainability of agriculture. In general, surface and pressurized irrigation systems can attain a reasonable level of efficiency, when they are well designed, adequately operated and appropriately selected for specific conditions; because irrigation is site specific.

Automation of the irrigation systems (surface and pressurized) coupled with sensor and equipments to register the information of the irrigation process are important topic that must be developed in order to use the systems with their total potentiality.

Regulated deficit irrigation proposed to control vegetative growth in orchards produce, in addition, savings in irrigation water without reducing yield. Thus, deficit irrigation has been demonstrated as a useful tool to improve irrigation management at field scale for arid and semi-arid conditions.

\section{RESUMEN}

Diseño y manejo de sistemas de riego. Los sistemas de riego deberían ser un agente relevante para dar soluciones a la demanda creciente de alimentos, y el desarrollo, sustentabilidad y productividad del sector agrícola. El diseño, manejo, y operación de los sistemas de riego son factores cruciales para lograr un uso eficiente de los recursos hídricos y el éxito en la producción de cultivos y frutales. El objetivo de este artículo fue analizar conocimientos e investigaciones que permitan identificar los principales criterios y procesos para mejorar el diseño y manejo de los sistemas de riego, basados en el concepto básico de desarrollar una agricultura más eficiente y sostenible. El diseño y manejo de los sistemas de riego deben tener su base en criterios que sean relevantes, lo que implica considerar aspectos agronómicos, de suelo, hidráulicos, económicos, energéticos, y ambientales. El diseño y manejo óptimo de los sistemas de riego a nivel predial es un factor de primera importancia para un uso racional del agua, el desarrollo económico de la agricultura y su sustentabilidad ambiental.

Palabras clave: riego, diseño, manejo de agua, operación de sistemas. 


\section{LITERATURE CITED}

Abbott, J.D., and R.E. Gough. 1986. Split-root water application to highbush blueberry plants. HortScience 21:997-998.

Al-Jamal, M.S., S. Ball, and T.W. Sammis. 2001. Comparison of sprinkler, trickle and furrow irrigation efficiencies for onion production. Agric. Water Manage. 46:253-266.

Asare, D.K., T. Sammis, D. Smeal, H. Zhang, and D.O. Sitze. 2001. Modelling an irrigation strategy for minimizing the leaching of atrazine. Agric. Water Manage. 48:225-238.

Bassoi, L.H, J.W. Hopmans, L.A. de C. Jorge, C.M. de Alencar, and J. Silva. 2003. Grapevine root distribution in drip and microsprinkler irrigation. Sci. Agric. (Piracicaba, Braz.) 60:377-387.

Bekele, S., and K. Tilahun. 2007. Regulated deficit irrigation scheduling of onion in a semiarid region of Ethiopia. Agric. Water Manage. 89:148-152.

Bozkurt, Y., A. Yazar, B. Gencel, and M.S. Sezen. 2006. Optimum lateral spacing for drip-irrigated corn in the Mediterranean Region of Turkey. Agric. Water Manage. 85:113-120.

Bravdo, B., and A. Naor. 1996. Effects of water regime on productivity and quality of fruit and wine. Acta Hort. (ISHS) 427:15-26.

Bryla, D.R., E. Dickson, R. Shenk, R.S. Johnson, C.H. Crisosto, and T.J. Trout. 2005. Influence of irrigation method and scheduling on patterns of soil and tree water status and its relation to yield and fruit quality in peach. HortScience 40:2118-2124.

Burguete, J., N. Zapata, P. García-Navarro, M. Maïkaka, E.Playán, and J. Murillo. 2009a. Fertigation in furrows and level furrows systems. I. Model description and numerical test. J. Irrig. Drain. Eng. 135:401-412.

Burguete, J., N.Zapata,P. García-Navarro, M. Maïkaka, E. Playán, and J. Murillo. 2009b. Fertigation in furrows and level furrows systems. II. Field experiments, model calibration, and practical applications. J. Irrig. Drain. Eng. 135:413-420.

Cai, X., D.C. McKinney, and M.W. Rosegrant. 2003. Sustainability analysis for irrigation water management in the Aral Sea region. Agric. Syst. 76:1043-1066.

Colombo, A., and D. Or. 2006. Plant water accessibility function: A design and management tool for trickle irrigation. Agric. Water Manage. 82:45-62.

Domingo, R., M.C. Ruiz-Sánchez, N.J. Sánchez-Blanco, and A. Torrecillas. 1996. Water relations, growth and yield of Fino lemon trees under regulated deficit irrigation. Irrig. Sci. 16:115-123.
Edstrom, J.P., and L.J. Schwankl. 2002. Microirrigation of almonds. Acta Hort. (ISHS) 591:505-508.

Eldeiry, A., L.A. Garcia, A.S. El-Zaher, and M.E. Kiwan. 2005. Furrow irrigation system design for clay soils in arid regions. Appl. Eng. Agric. 21:411-420.

English, M.J., K.H. Solomon, and G.J. Hoffman. 2002. A paradigm shift in irrigation management. J. Irrig. Drain. Eng. 128:267-277.

Fabeiro, C., F. Martín de Santa Olalla, R. López, and A. Domínguez. 2003. Production and quality of the sugar beet (Beta vulgaris L.) cultivated under controlled deficit irrigation conditions in a semi-arid climate. Agric. Water Manage. 62:251-227.

Falkenberg, N., G. Piccinni, J.T. Cothren, D.I. Leskovar, and C.M. Rush. 2007. Remote sensing of biotic and abiotic stress for irrigation management of cotton. Agric. Water Manage. 87:23-31.

Farré, I., and J.M. Faci. 2006. Comparative response of maize (Zea mays L.) and sorghum (Sorghum bicolor L. Moench) to deficit irrigation in a Mediterranean environment. Agric. Water Manage. 83:135-143.

Fereres, E., and M.A. Soriano. 2007. Deficit irrigation for reducing agricultural water use. J. Exp. Bot. 58:147159.

Girona, J., M. Gelly, M. Mata, A. Arbonés, J. Rufat, and J. Marsal. 2005a. Peach tree response to single and combined deficit irrigation regimes in deep soils. Agric. Water Manage. 72:97-108.

Girona, J., M. Mata, E. Fereres, D.A. Goldhamer, and M. Cohen. 2004. Evapotranspiration and soil water dynamics of peach trees under water deficits. Agric. Water Manage. 54:107-122.

Girona, J., M. Mata, and J. Marsal. 2005b. Regulated deficit irrigation during the kernel-filling period and optimal irrigation rates in almond. Agric. Water Manage. 75:152-167.

Goldhamer, D.A., and R.H. Beede. 2004. Regulated deficit irrigation effects on yield, nut quality and water-use efficiency of mature pistachio trees. J. Hort. Sci. Biotechnol. 79:538-545.

Goldhamer, D.A., M. Viveros, and M. Salinas. 2006. Regulated deficit irrigation in almonds: effects of variations in applied water and stress timing on yield and yield components. Irrig. Sci. 24:101-114.

González-Altozano, P., and J.R. Castel. 1999. Regulated deficit irrigation in 'Clementina de Nules' citrus trees. I. Yield and fruit quality effects. J. Hort. Sci. Biotechnol. 74:706-713.

Hadas, A., A. Hadas, B. Sagiv, and N. Haruvy. 1999. Agricultural practices, soil fertility management modes and resultant nitrogen leaching rates under semi-arid conditions. Agric. Water Manage. 42:81-95. 
Hanson, B., and D. May. 2004. Effects of subsurface drip irrigation on processing tomato yield, water table depth, soil salinity, and profitability. Agric. Water Manage. 68:1-17.

Hazrat, A., L. Teang Shui, and W.R. Walker. 2003. Optimal water management for reservoir based irrigation projects using Geographic Information System. J. Irrig. Drain. Eng. 129:1-10.

Henríquez, K. 2005. Efecto de la localización y aplicación de agua y fertilizante en la producción y calidad de naranjas cv. Valencia. 154 p. Tesis Ingeniero Civil Agrícola. Universidad de Concepción, Facultad de Ingeniería Agrícola, Chillán, Chile.

Hillel, D., and P. Vlek. 2005. The sustainability of irrigation. Adv. Agron. 87:55-84.

Holzapfel, E.A., W.A. Abarca, V.P. Paz, A. Rodríguez, X. Orrego, y M.A. López. 2007a. Selección técnicoeconómico de emisores. Rev. Bras. Eng. Agric. Ambiental 11:456-463.

Holzapfel, E., y J.L. Arumí. 2006. Interim Report. Tecnología de manejo de agua para una agricultura intensiva sustentable. 70 p. Proyecto D02I-1146. Universidad de Concepción, Facultad de Ingeniería Agrícola, Chillán, Chile.

Holzapfel, E.A., R.F. Hepp, and M.A. Mariño. 2004. Effect of irrigation on fruit production in blueberry. Agric. Water Manage. 67:173-184.

Holzapfel, E., R. Merino, M. Mariño, and R. Matta. 2000. Water production function in kiwi. Irrig. Sci. 19:73-80.

Holzapfel, E.A., X. Pardo, V.P. Paz, A. Rodríguez, X. Orrego, y M.A. López. 2007b. Análisis técnicoeconómico para selección de aspersores. Rev. Bras. Eng. Agric. Ambiental 11:464-470.

Hsiao, T.C., P. Steduto, and E. Fereres. 2007. A systematic and quantitative approach to improve water use efficiency in agriculture. Irrig. Sci. 25:209-231.

Hutmacher, R.B., H.I. Nightingale, D.E. Rolston, J.W. Biggar, F. Dale, S.S. Vail, and D. Peters. 1994. Growth and yield responses of almond (Prunus amygdalus) to trickle irrigation. Irrig. Sci. 14:117-126.

Ibragimov, N., S.R. Evett, Y. Esanbekov, B.S. Kamilov, L. Mirzaev, and J.P.A. Lamers. 2007. Water use efficiency of irrigated cotton in Uzbekistan under drip and furrow irrigation. Agric. Water Manage. 90:112-120.

Intrigliolo, D.S., and J.R. Castel. 2006. Performance of various water stress indicators for prediction of fruit size response to deficit irrigation in plum. Agric. Water Manage. 83:173-180

Jalota, S.K., A. Sood, G.B.S. Chahal, and B.U. Choudhury. 2006. Crop water productivity of cotton (Gossypium hirsutum L.) - wheat (Triticum aestivum L.) system as influenced by deficit irrigation, soil texture and precipitation. Agric. Water Manage. 84:37-146.
Karlberg, L., J. Rockstrom, J.G. Annandale, and J.M. Steyn. 2007. Low-cost drip irrigation: A suitable technology for southern Africa? An example with tomatoes using saline irrigation water. Agric. Water Manage. 89:59-70.

Khan, S., R. Tariq, C. Yuanlai, and J. Blackwell. 2006. Can irrigation be sustainable? Agric. Water Manage. 80:87-99.

Kumar,R., and J.Singh. 2003. Regional water management modelling for decision support in irrigated agriculture. J. Irrig. Drain. Eng. 129:432-439.

Lehrsch, G.A., R.E. Sojka, and D.T. Westermann. 2000. Nitrogen placement, row, spacing, and furrow irrigation water positioning effects on corn yield. Agron. J. 92:1266-1275.

Maisiri N., A. Sanzanje, J. Rockstrom, and S.J. Twomlow. 2005. On farm evaluation of the effect of low cost drip irrigation on water and crop productivity compared to conventional surface irrigation system. Phys. Chem. Earth 30:783-791.

McCarthy, M.G., B.R. Loveys, P.R. Dry, and M. Stoll. 2002. Regulated deficit irrigation and partial rootzone drying as irrigation management techniques for grapevines. In Deficit irrigation practices. Water Reports $N^{\circ}$. 22. p. 7987. FAO, Rome, Italy (Available at http://www.fao.org/ docrep/004/y3655e/y3655e11.htm).

Moriana, A., F. Orgaz, M. Pastos, and E. Fereres. 2003. Yield responses of mature olive orchard to water deficits. J. Amer. Soc. Hort. Sci. 123:425-431.

Ortiz Romero, J.N., J. Martínez, R. Martínez, and J.M Tarjuelo. 2006. Set sprinkler irrigation and its cost. J. Irrig. Drain. Eng. 132:445-452.

Pannunzio, A. 2008. Efectos de sustentabilidad de los sistemas de riego por goteo en arándanos. 113 p. Tesis Mg.Sc. Universidad de Buenos Aires, Facultad de Ciencias Veterinarias, Buenos Aires, Argentina.

Pannunzio, A., and J. Genoud. 2000. Four trickle irrigation treatments in four varieties of oranges. $p$ 629-635. Proceedings of the IV Decennial National Irrigation Symposium, Phoenix, Arizona, USA. 1416 November. American Society of Agricultural Engineers (ASAE), St. Joseph, Michigan, USA.

Pannunzio, A., J. Genoud, F. Covatta, T. Barilari, and A. Agulla. 2000. Trickle irrigation assessments with orange varieties in Argentina. p. 34-35. Proceedings of the VI International Microirrigation, Cape Town, South Africa.

Pannunzio, A., M. Román, J. Brenner, and A. Wölfle. 2004b. Economic overview of drip and microirrigation systems in humid regions. p. 52. Proceedings of the VII World Citriculture Congress, Agadir, Marruecos. International Society of Citriculture (ISC), Riverside, California, USA. 
Pannunzio, A., M. Román, A. Wölfle, and J. Brenner. 2004a. Design and operation decisions in drip and microirrigation systems, as a tool to achieve better quality and profitability in citriculture. p. 51 . Proceedings of International Congress on Citriculture, Agadir, Marruecos. International Society of Citriculture (ISC), Riverside, California, USA.

Pannunzio, A., P. Texeira, D. Pérez, G. Sbarra, y A. Grondona. 2008. Efectos de sustentabilidad de los sistemas de riego de arándanos en la Pampa Húmeda. p. 24-25. Libro de Resúmenes del I Congreso Latinoamericano de Arándanos y otros berries. Agosto 2008. Universidad de Buenos Aires, Facultad de Agronomía (FAUBA), Buenos Aires, Argentina.

Payero, J.O., S.R. Melvin, S. Irmak, and D. Tarkalson. 2006. Yield response of corn to deficit irrigation in a semiarid climate. Agric. Water Manage. 84:101-112.

Pereira, L. 1999. Higher performance through combined improvements in irrigation methods and scheduling: a discussion. Agric. Water Manage. 40:153-169.

Playán, E., and L. Mateos. 2006. Modernization and optimization of irrigation systems to increase water productivity. Agric. Water Manage. 80:100-116.

Popova, Z., D. Crevoisier, P. Ruelle, and J.C. Mailhol. 2005. Application of Hydrus2D model for simulating water transfer under furrow irrigation - Bulgarian case study in cropped lysimeters on Chromic Luvisol. p. 1-13. ICID 21 th European Regional Conference, Frankfurt, Germany. International Commission on Irrigation and Drainage (ICID), New Delhi, India.

Quiñones, P.H, H. Unland, W. Ojeda, and E. Cifuentes. 1999. Transfer of irrigation scheduling technology in Mexico. Agric. Water Manage. 40:333-339.

Ramalan, A.A., and R.W. Hill. 2000. Strategies for water management in gravity sprinkle irrigation systems. Agric. Water Manage. 43:51-74.

Ravindra, V.K., R.P. Singh, and P.S Mahar. 2008. Optimal design of pressurized irrigation subunit. J. Irrig. Drain. Eng. 134:137-146.

Rice, R.C., D.J. Hunsaker, F.J. Adamsen, and A.J. Clemmens. 2001. Irrigation and nitrate movement evaluation in conventional and alternate-furrow irrigated cotton. Trans. ASAE 44:555-568.

Rodríguez,A. 2001. Uso de GIS para diseño de riego. Tesis Ingeniero Civil Agrícola. Universidad de Concepción, Facultad de Ingeniería Agrícola, Chillán, Chile.

Rodríguez, J., L.R. Sánchez, and A. Losada. 2007. Evaluation of drip irrigation: Selection of emitters and hydraulic characterization of trapezoidal units. Agric. Water Manage. 90:13-26.
Romero, P., P. Botia, and F. Garcia. 2004. Effects of regulated deficit irrigation under subsurface drip irrigation conditions on water relations of mature almond trees. Plant Soil 260:155-168.

Romero, P., J. Garcia, and P. Botia. 2006. Cost-benefit analysis of a regulated deficit-irrigated almond orchard under subsurface drip irrigation conditions in Southeastern Spain. Irrig. Sci. 24:175-184.

Sepulcre-Cantó G., P.J. Zarco-Tejada, J.C. JiménezMuñoz, J.A. Sobrino, E. de Miguel, and F.J. Villalobos. 2006. Detection of water stress in an olive orchard with thermal remote sensing imagery. Agric. For. Meteorol. 136:31-44.

Tognetti, R., R. d'Andria, A. Lavini, and G. Morelli. 2006. The effect of deficit irrigation on crop yield and vegetative development of Olea europaea L. (cvs. Frantoio and Leccino). Eur. J. Agron. 25:356-364.

Tognetti, R., R. d'Andria, G. Morelli, and A. Alvino. 2005. The effect of deficit irrigation on seasonal variations of plant water use in Olea europaea L. Plant Soil 273:139-155.

Tognetti, R., M. Palladino, A. Minnocci, S. Delfine, and A. Alvino. 2003. The response of sugar beet to drip and low-pressure sprinkler irrigation in southern Italy. Agric. Water Manage. 60:135-155.

Troy, Peters, R., and S.R. Evett. 2008. Automation of center pivot using the temperature-time-threshold method of irrigation schedule. J. Irrig. Drain. Eng. 134:286-291.

Velez, J.E., D.S. Intrigliolo, and J.R. Castel. 2007. Scheduling deficit irrigation of citrus trees with maximum daily trunk shrinkage. Agric. Water Manage. 90:197-204.

Wichelns, D., and J.D. Oster. 2006. Sustainable irrigation is necessary and achievable, but direct costs and environmental impacts can be substantial. Agric. Water Manage. 86:114-127.

Yadav, B.K., and S. Mathur. 2008. Modeling soil water uptake by plants using nonlinear dynamic root density distribution function. J. Irrig. Drain. Eng. 134:430436.

Yazar, A., S.M. Sezen, and S. Sesveren. 2002. LEPA and trickle irrigation of cotton in the Southeast Anatolia Project (GAP) area in Turkey. Agric. Water Manage. 54:189-203. 